\title{
Retinal Morphology and Visual Specializations in Three Species of Chimaeras, the Deep-Sea $R$. pacifica and C. lignaria, and the Vertical Migrator C. milii (Holocephali)
}

\author{
Eduardo Garza-Gisholt ${ }^{a, b}$ Nathan S. Hart ${ }^{a, c}$ Shaun P. Collin ${ }^{a}$ \\ a School of Biological Sciences, The University of Western Australia, Crawley, WA, Australia; ${ }^{\text {b Centro de }}$ \\ Investigaciones y Estudios Avanzados CINVESTAV IPN Mérida, Yucatán, Mexico; 'Department of Biological Sciences, \\ Macquarie University, Sydney, NSW, Australia
}

\section{Keywords}

Chimaera · Visual ecology · Ganglion cell · Photoreceptor · Spatial resolving power $\cdot$ Retinal summation $\cdot R$ Project for Statistical Computing

\begin{abstract}
The majority of holocephalans live in the mesopelagic zone of the deep ocean, where there is little or no sunlight, but some species migrate to brightly lit shallow waters to reproduce. This study compares the retinal morphology of two species of deep-sea chimaeras, the Pacific spookfish (Rhinochimaera pacifica) and the Carpenter's chimaera (Chimaera lignaria), with the elephant shark (Callorhinchus milii), a vertical migrator that lives in the mesopelagic zone but migrates to shallow water to reproduce. The two deep-sea chimaera species possess pure rod retinae with long photoreceptor outer segments that might serve to increase visual sensitivity. In contrast, the retina of the elephant shark possesses rods, with an outer-segment length significantly shorter (a mean of $34 \mu \mathrm{m}$ ) than in the deep-sea species, and cones, and therefore the potential for color vision. The retinal ganglion cell distribution closely follows that of the photoreceptor
\end{abstract}

\section{KARGER}

(c) 2018 S. Karger AG, Basel

E-Mail karger@karger.com

www.karger.com/bbe populations in all three species, but there is a lower peak density of these cells in both deep-sea species (215-275 cells $/ \mathrm{mm}^{2}$ vs. 769 cells $/ \mathrm{mm}^{2}$ in the elephant shark), which represents a significant increase in the convergence of visual information (summation ratio) from photoreceptors to ganglion cells. It is evident that the eyes of deep-sea chimaeras have increased sensitivity to detect objects under low levels of light, but at the expense of both resolution and the capacity for color vision. In contrast, the elephant shark has a lower sensitivity, but the potential for color discrimination and a higher visual acuity.

(C) 2018 S. Karger AG, Basel

\section{Introduction}

Chimaeras (subclass Holocephali) are one of the most ancient groups of vertebrates. They are cartilaginous fishes, closely related to sharks and rays (subclass Elasmobranchii), which all belong to the Chondrichthyes, a class that evolved in the Silurian Period over 400 million years ago [Inoue et al., 2010]. The holocephalians are a less diverse group than the elasmobranchs, with only about 47 
extant species described from the $>1,200$ species of chondrichthyans [Lund and Grogan, 1997; Last and Stevens, 2009; Lisney, 2010]. There are three different families within the order Holocephali: Chimaeridae, Rhinochimaeridae, and Callorhinchidae. This study examines one member of each of these families; the Carpenter's chimaera (Chimaera lignaria: Chimaeridae), the Pacific spookfish (Rhinochimaera pacifica: Rhinochimaeridae), and the elephant shark (Callorhinchus milii: Callorhinchidae).

Very little is known about the biology of chimaerids, but, like sharks, they mature late, give birth to a small number of offspring, and have no parental care [Compagno et al., 2005; Garcia et al., 2008]. Isolated reports on their diet reveal that Chimaera monstrosa [Bergstad et al., 2003], Hydrolagus spp. [Marques and Porteiro, 2000; Moura et al., 2005; Gonzalez et al., 2007], and Harriota raleighana [Dunn et al., 2010] all feed on benthic invertebrates like crustaceans, ophiurids, polychaete worms, and urchins. However, there is a dietary difference between Harriota spp. (Rhinochimaeridae) that feed predominantly on benthic invertebrates, and Hydrolagus spp. (Chimaeridae) that feed primarily on pelagic molluscs like cephalopods [Gonzalez et al., 2007].

Their large prominent eyes, the variable light environment in which they live, and their relationship with basal vertebrates make the chimaeras one of the most interesting groups to study with respect to the evolution of their visual system and their visual ecology [Ebert, 2003; Compagno et al., 2005]. Some species live in the mesopelagic zone at $>500 \mathrm{~m}$, where there are low levels of sunlight [Didier, 1998, 2004; Compagno, 2001; Last and Stevens, 2009], and frequent bioluminescent emissions produced by a large range of vertebrates and invertebrates that indicate potential prey or predator [Herring, 1977, 2000; Warrant and Locket, 2004]. Chimaeras living in this "twilight zone" may have adaptations to either increase sensitivity, as the levels of sunlight diminish with depth, or enhance resolution to localize small sources of bioluminescence against an otherwise featureless background [Warrant and Locket, 2004]. The elephant shark (C. milii), which normally lives in deep water, migrates to shallow, brightly lit water to reproduce, thereby placing demands on the visual system with respect to optimizing sensitivity and resolution [Last and Stevens, 2009].

Over the last decade, vision has been studied intensively in elasmobranchs, but chimaeras have received little attention and require more comparative studies [Hart et al., 2006; Lisney, 2010]. Despite living in low-light environments, some species of chimaerids have prominent eyes, which are relatively large with respect to their body size [Didier, 2004; Lisney, 2010]. Large eyes represent a specialization to increase sensitivity, especially in deepsea species, where the amount of light available for vision is limited [Warrant and Locket, 2004; Lisney and Collin, 2007; Douglas, 2010]. The pupil of the eye in most deepsea elasmobranchs shows little or no ability to change size, remaining dilated to increase the amount of light entering the eye [Kuchnow, 1971; Maddock and Nicol, 1978; Bozzano et al., 2001]. Some species of chimaeras also possess a tapetum lucidum, a reflective layer of cells behind the retina that increases sensitivity by reflecting light back onto the photoreceptors [Denton and Nicol, 1964; Maddock and Nicol, 1978; Didier, 2004]. Species that live in the mesopelagic zone also have specializations to optimize light absorption, such as the marked elongation of their photoreceptor outer segments [Land, 1981; Warrant and Locket, 2004].

The analysis of retinal cell distribution, especially the photoreceptors and the retinal ganglion cells, is a powerful technique to infer the visual ecology of species that are hard to observe in their natural environment [Collin, 1999, 2008]. Photoreceptor cells (rods and cones) are responsible for light detection; rod photoreceptors possess long outer segments to enhance photon capture (and thus sensitivity) and operate in dim-light conditions, while cones possess smaller, tapered outer segments that operate in high light intensities. If a species possesses more than one type of cone photoreceptor, each containing a visual pigment with a different peak spectral sensitivity, it has the potential for color vision [Carter, 1948].

Most chimaeras are reported to have a pure rod retina with a visual pigment tuned to maximally absorb the wavelengths of light available in deep water. The rod visual pigments of most deep-sea fishes contain a chromophore based on vitamin $A_{1}$ that absorbs wavelengths between 470 and $490 \mathrm{~nm}$ [Denton and Shaw, 1963; Beatty, 1969; Crescitelli, 1969; Partridge et al., 1989; Douglas et al., 1995; Fröhlich et al., 1995]. Although little is known about the photoreceptors in chimaerids, Vigh-Teichman et al. [1990] characterized two types of rods based on immunohistochemical and ultrastructural criteria in the rabbit fish, C. monstrosa. More recently, Davies et al. [2009] showed that the retina of the elephant shark, C. milii, possesses a single type of rod opsin gene $(R h 1)$ and three cone opsin genes (middle wavelength-sensitive $R h 2$, and two isoforms of long wavelength-sensitive; $L W S 1$ and $L W S 2$ ), thereby providing the potential for color vision.

Many studies on the distribution of ganglion cells (total population or subtypes) in the retina of elasmobranchs
48

Brain Behav Evol 2018;92:47-62 DOI: $10.1159 / 000490655$
Garza-Gisholt/Hart/Collin 
reveal a range of specializations for acute vision subtending different regions of each species' visual field [Hueter, 1991; Bozzano and Collin, 2000; Bozzano, 2004; Theiss et al., 2007; Litherland and Collin, 2008; Muguruma et al., 2013]. However, very few studies have concentrated on the topography of the ganglion cells in chimaeras, with the exception of one on the spotted ratfish, Hydrolagus colliei [Collin, 1999], and another on the large-eyed rabbitfish, Hydrolagus mirabilis [Bozzano and Collin, 2000]. Both studies revealed there is a pronounced horizontal streak or elongated increase in cell density across the dorsal meridian of the retina.

No studies have examined the convergence of photoreceptor cells onto ganglion cells (convergence ratio) in the retina of chimaeras, which is a quantitative indicator of sensitivity and resolution [Litherland and Collin, 2008; Douglas, 2010]. The calculation of optical sensitivity is also useful to assess the level of visual specialization to different light intensities in chimaerids, particularly in species occupying different habitats. The number of photons detected by each photoreceptor can be estimated and used to give a measure of the sensitivity of the retina and therefore the whole eye. Strategies to increase photon capture by the photoreceptors include increasing the optical aperture (cross-sectional area and acceptance angle) and photoreceptor outer-segment length. The elongation of the outer segments can be found in some teleost fishes that live in the mesopelagic zone, like lanternfishes (Myctophidae) [de Busserolles and Marshall, 2017] and the blue marlin, Makaira nigricans, which has an optical sensitivity of $1.5 \mu \mathrm{m}^{2}$ sr [Fritsches et al., 2003]. Optical sensitivity can vary greatly across taxa. For example, some teleost fishes have an optical sensitivity of between 1.5 and $6 \mu \mathrm{m}^{2} \mathrm{sr}$, while marine invertebrates, such as the deep-sea crustacean Oplophorus sp., have a sensitivity of up to $3,300 \mu \mathrm{m}^{2}$ sr [Land, 1981].

This study examines the retinal morphology of three species of chimaeras from two different habitats (deep sea and shallow water) and reveals specializations for higher sensitivity in the two deep-sea species, $R$. pacifica and $C$. lignaria, and specializations for enhanced resolution in the migratory species, $C$. milii.

\section{Materials and Methods}

\section{Collection of Animals}

Elephant sharks (C. milii) (63-90 cm TL; five males and six females) were collected in shallow water off the coast of Victoria, Australia (Western Port Bay) using rod and reel with the Department of Fisheries (permit No. RP1041). The animals were trans- ported to the Department of Primary Industries (DPI) facilities in Queenscliff for additional physiological experiments, and were euthanized using an overdose of tricaine methane sulfonate (MS222; 1:2,000 in seawater) according to the ethics guidelines of The University of Western Australia (AEC RA/3/100/9).

The deep-sea chimaeras, $R$. pacifica (104-119 cm TL; five males and two females) and C. lignaria (86-160 cm TL; one male and two females), were collected off the coast of New Zealand from the boat "Sea Mount" operated by Anton's Seafoods Ltd., a company based in Auckland, NZ, that was targeting orange roughy and catching deep-sea sharks and chimaeras as bycatch. The animals were dead when brought onto the boat, but sufficiently fresh for carrying out anatomical studies following preservation.

\section{Eye Dissection and Visualization of Photoreceptors and} Ganglion Cells

The eyes of each individual were measured longitudinally (rostrocaudally) and axially (mediolaterally) using a pair of digital vernier calipers. A small lesion was made in the ventral part of the eyecup (prior to eye removal) for orientation. The eyes were then enucleated and the cornea, lens, and iris removed to expose the fundus. The lens was measured using a pair of digital vernier calipers. The eyecup was immersed in $4 \%$ paraformaldehyde in $0.1 \mathrm{M}$ phosphate buffer ( $\mathrm{pH} 7.2-7.4)$ for a maximum of 14 days, and then transferred to a mixture of $0.1 \mathrm{M}$ phosphate buffer and $1 \%$ sodium azide $(\mathrm{pH} 7.2-7.4)$ and stored at $4{ }^{\circ} \mathrm{C}$. Three retinas per species were carefully dissected free of the eyecup, and radial cuts were made to flatten the retina and aid in the removal of the scleral and choroidal layers. The pigment epithelium was removed using fine forceps and a fine natural-hair paint brush.

The retina was first flattened onto a glass slide, photoreceptor layer facing up, and mounted under a coverslip in 100\% glycerol. The coverslip was sealed using nail polish to prevent the retina from drying out. After 2-3 days, the retina had cleared sufficiently in the glycerol, so that the morphology and topographic density distribution of the photoreceptors could be analyzed using conventional transmitted light microscopy (see below). The cones and rods were visible in axial view, and could be distinguished (based on their position and size) by changing the fine focus on the microscope $(\times 600)$.

After completion of the photoreceptor analysis, the retina was washed in $0.1 \mathrm{M}$ phosphate buffer ( $\mathrm{pH} 7.2-7.4$ ) to remove the glycerol. The retina was then mounted ganglion cell layer upwards on a gelatinized slide and incubated overnight in formaldehyde vapor. The retina was hydrated and stained for Nissl substance with an aqueous solution of $0.1 \%$ cresyl violet ( $\mathrm{pH} 3.8$ ) for 2 min, dehydrated using a graded series of ethanols [Stone, 1981; Coimbra et al., 2006, 2009], and cleared (twice) in xylene. It was then coverslipped with Entellan New (Merck Millipore) and allowed to set for $24 \mathrm{~h}$ before counting.

Ganglion cells were distinguished by their large and irregularly shaped soma and granular staining of the Nissl substance present in the cytoplasm, different from the smaller and more circular amacrine cell soma [Collin and Pettigrew, 1988a; Bozzano and Collin, 2000]. Only orthotopic ganglion cells located in the ganglion cell layer were analyzed. In some cartilaginous fishes, a proportion of ganglion cells are located in the inner plexiform and inner nuclear layers of the retina, but these cells are relatively sparsely distrib- 
uted and can be difficult to stain and/or visualized [Muguruma et al., 2014]. So we ignored them in this study, although we recognize that doing so can result in an underestimation of ganglion cell density and thus spatial resolving power (SRP).

Assessment of the topographic distribution of photoreceptors and ganglion cells was conducted using a nonbiased stereological method, with the aid of a compound microscope (Olympus BX50) connected to an automatic motorized stage (MAC200, Ludl Electronic Products, USA) and Stereo Investigator, RRID: SciRes_000114 (Microbrightfields, USA). The outline of the retina, including the peripheral incisions, was traced using a $\times 4 \mathrm{NA}$ 0.13 objective. The outline of the acellular optic nerve head was also traced and excluded from the counting area. The retinal outline data and the cell counts were exported as an Extensible Markup Language (.xml) format file and analyzed using the open source software R Project for Statistical Computing, RRID:nif-0000-10474 [R Core Team, 2012] and additional packages [Baddeley and Turner, 2005; Wickham, 2009, 2012; Nychka et al., 2012; R Studio, 2012] using custom script for the construction of retinal topographic maps [Garza-Gisholt et al., 2014]. The uncalibrated cell counts were transformed to a density value of cells per $\mathrm{mm}^{2}$ with the formula:

$$
\text { Cells } \mathrm{mm}^{-2}=Q \frac{1,000,000}{c f},
$$

where $Q$ is the number of cells counted in each sampling site and $c f$ is the counting frame in $\mu \mathrm{m}^{2}$. Topographic maps for the spatial distribution of cell density were obtained using an undersmoothed thin-plate spline from the sp package [Garza-Gisholt et al., 2014].

Three topographic maps were constructed for each species for each type of cell (rods, cones, and ganglion cells). Since the size of all individuals of each species was similar, with no more than a $5 \%$ variation in the total retinal area, all maps were standardized to the largest retina by aligning the position of the optic nerve head as a reference, and then using the proportional distance to the edge to calculate the new set of coordinates for the contour and the observed data. The total number of cells was not calculated from the corrected map but for each single stereological procedure. A grid of retinal loci (every $200 \mu \mathrm{m}$ on the $x$ and $y$ axes) was used to calculate the cell density values for each retina in the same position. The mean of each cell density was calculated to obtain an average topographic map. The final map was outlined using an oval of the dimensions of the largest retina. This map does not represent a hemispherical orientation, but simply removes the radial cuts made to flatten the retina (since cuts were not placed in the same position). The spline method adjusts the values that are close to the edge of the cuts, using a spatial algorithm to correct any artefacts due to shrinkage and/or distortion. A surface representation of the spatial arrangement of points was obtained, with the contour lines representing areas of equal cell density.

\section{Retinal Summation Maps and Calculations of SRP}

Summation ratios comparing the density of rod photoreceptor cells and ganglion cells at each retinal locus were calculated using the average maps (see above) for each species. The two topography maps were aligned with the optic nerve head as a reference point, where the grid of calculated average cell densities was then used to obtain the number of rods per ganglion cell.
These summation ratios were plotted and iso-density contours constructed using the same technique as for the single-cell type maps.

The highest density of ganglion cells was used to calculate the SRP, assuming a square mosaic distribution according to Collin and Pettigrew [1989] and Fristches et al. [2003]:

$$
\text { cycles per degree }=\left(\frac{1}{2}\right)\left(\frac{\sqrt{n}}{\arctan \left(\frac{1}{2.55 r}\right)}\right) \text {. }
$$

One can also make the calculation based on a hexagonal mosaic distribution of ganglion cells according to Hart [2002] and Theiss et al. [2007]:

$$
\text { cycles per degree }=\left(\frac{1}{2}\right) \times\left(\frac{2 \pi \times 2.55 \times r}{360}\right) \times \sqrt{\left(\frac{2 n}{\sqrt{3}}\right)},
$$

where $r$ is the axial radius of the lens along the optical axis, which is multiplied by 2.55 according to Matthiessen's ratio to estimate the focal length and $\mathrm{n}$ is the highest cell density in the area centralis [Matthiessen, 1880].

\section{Histology of the Retina and the Calculation of Optical \\ Sensitivity}

Small pieces of retina fixed in Karnovsky's solution (2.5\% glutaraldehyde, $2 \%$ paraformaldehyde in $0.1 \mathrm{M}$ cacodylate buffer $\mathrm{pH}$ 7.4) were dissected out of the eyecup, embedded in araldite, and orientated for sectioning in the transverse plane. Using a microtome (LKB Bromma Ultratome Nova), 1- $\mu$ m-thick transverse sections were cut and mounted on a glass slide, stained using an aqueous solution of $1 \%$ Toluidine blue, and coverslipped using Entellan (Merck Millipore). Stained sections were photographed using an Olympus DP70 camera mounted on an Olympus BX50 compound microscope using $\times 40, \times 60$, and $\times 100$ objectives. Images were edited using Adobe Photoshop CS5 (brightness and contrast only), and 50 photoreceptor outer- and inner-segment measurements from 2 different areas of the retina (center and periphery) were obtained using ImageJ open-access software (RRID:nif-000030467) [Schneider et al., 2012].

The optical sensitivity equation of Land [1981] was used to compare the relative light-gathering ability of the rod photoreceptors in the 3 species. This calculation is based on the maximum absorption of monochromatic light by rod photoreceptors. The specific absorbance of the outer segment has been calculated by Partridge et al. [1989] for the narrownose chimaera Harriotta $r$. (Rhinochimaeridae) $(k=0.0123 \times 2.303=0.028 \mu \mathrm{m})$, and this gets used for all species in the absence of the actual microspectrophotometric measurements for these species. The absorbance $(F)$ of monochromatic light at the wavelength of maximum sensitivity $\left(\lambda_{\max }\right)$ of the rod pigment is given by:

$$
F \lambda_{\max }=1-e^{(-k l)} .
$$

Where $k$ is the naperian absorbance of the outer segment when illuminated axially and $l$ is the length of the outer segment.

Assuming that these deep-sea chimaeras do not change the size of their pupillary aperture [Maddock and Nicol, 1978], the sen- 

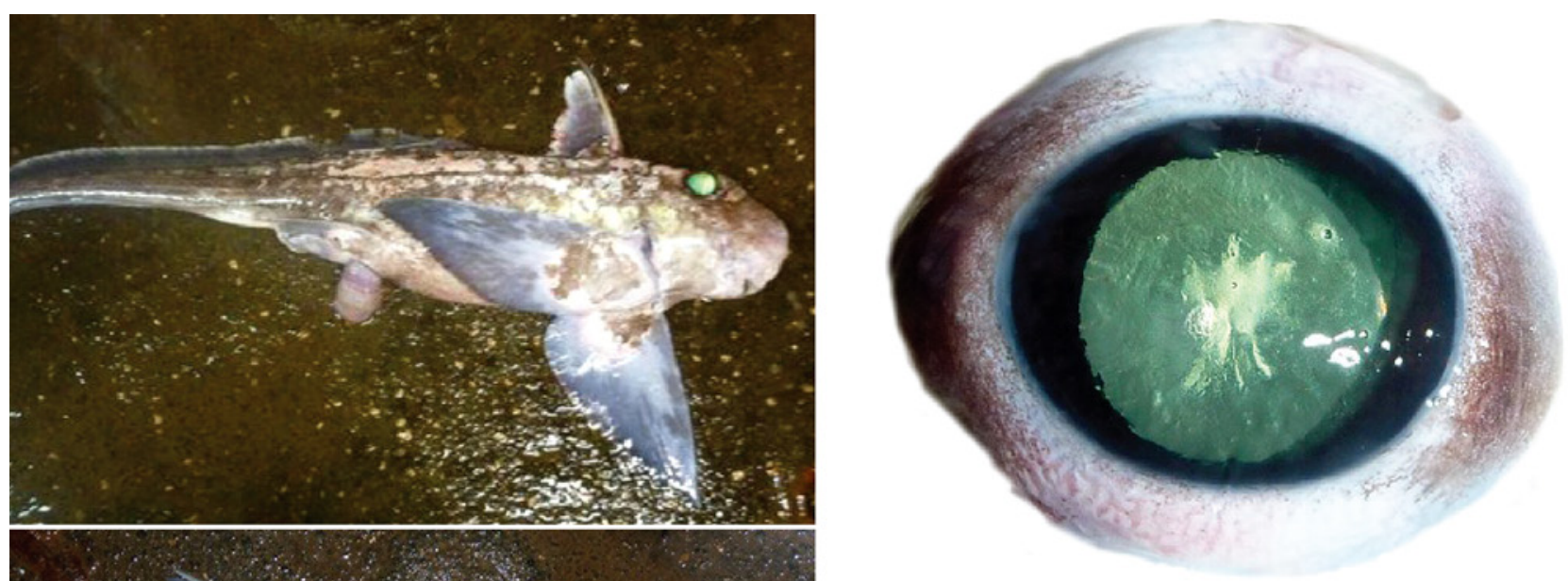

Fig. 1. The eyes of chimaeras and their tapetum lucidium. a Two species of deep-sea chimaeras: Carpenter's chimaera C. lignaria (top) and Pacific spookfish $R$. pacifica (bottom). b Enucleated eye of $R$. pacifica with the brightlight reflex produced by the tapetum lucidum. a, b Photos obtained by courtesy of Amy Newman. c Elephant shark C. milii in a keeping tank. d Eye of C. milii that does not show the bright-colored reflex from the tapetum lucidum.

sitivity of the rod photoreceptors at all depths is given by Land [1981]:

$$
S\left(\mu m^{2} s r\right)=\left(\frac{\pi}{4}\right)^{2} \times\left(\frac{A^{2}}{f}\right) \times d^{2} \times F \lambda_{\max },
$$

where $A$ is the diameter of the lens (as a proxy for the pupil diameter), $f$ is the focal length (posterior nodal distance) of the eye calculated from Matthiessen's ratio $(2.55 \times$ lens radius $)$, and $d$ is the inner-segment diameter that acts as a light guide and is used as a proxy for the optical aperture.

Retinal Morphology and Visual Specializations in Chimaeras Species

\section{Results}

The choroidal layer in the back of the retina produced a bright green coloration (reflex) in the deep-sea chimaeras $R$. pacifica and C. lignaria. This layer contains the tapetum lucidum, which appears to be comprised of a layer of reflective guanine crystals similar to those reported in elasmobranchs [Nicol and Somiya, 1989]. The elephant shark, C. milii, does not possess a tapetum lucidum (Fig. 1). 

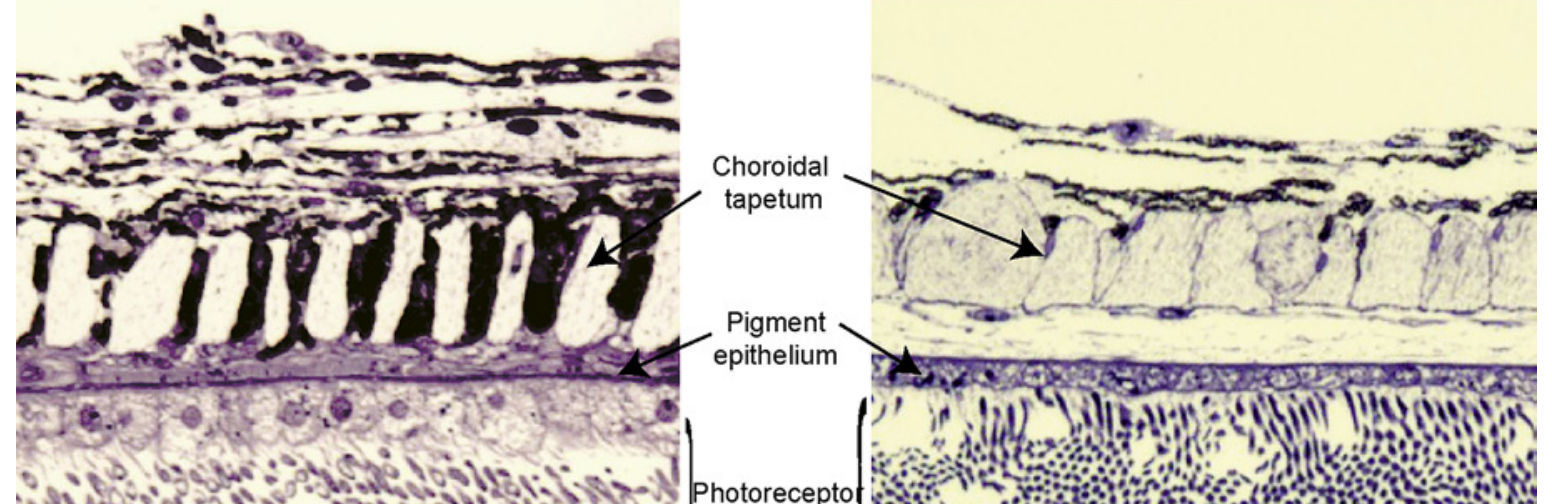

epithelium
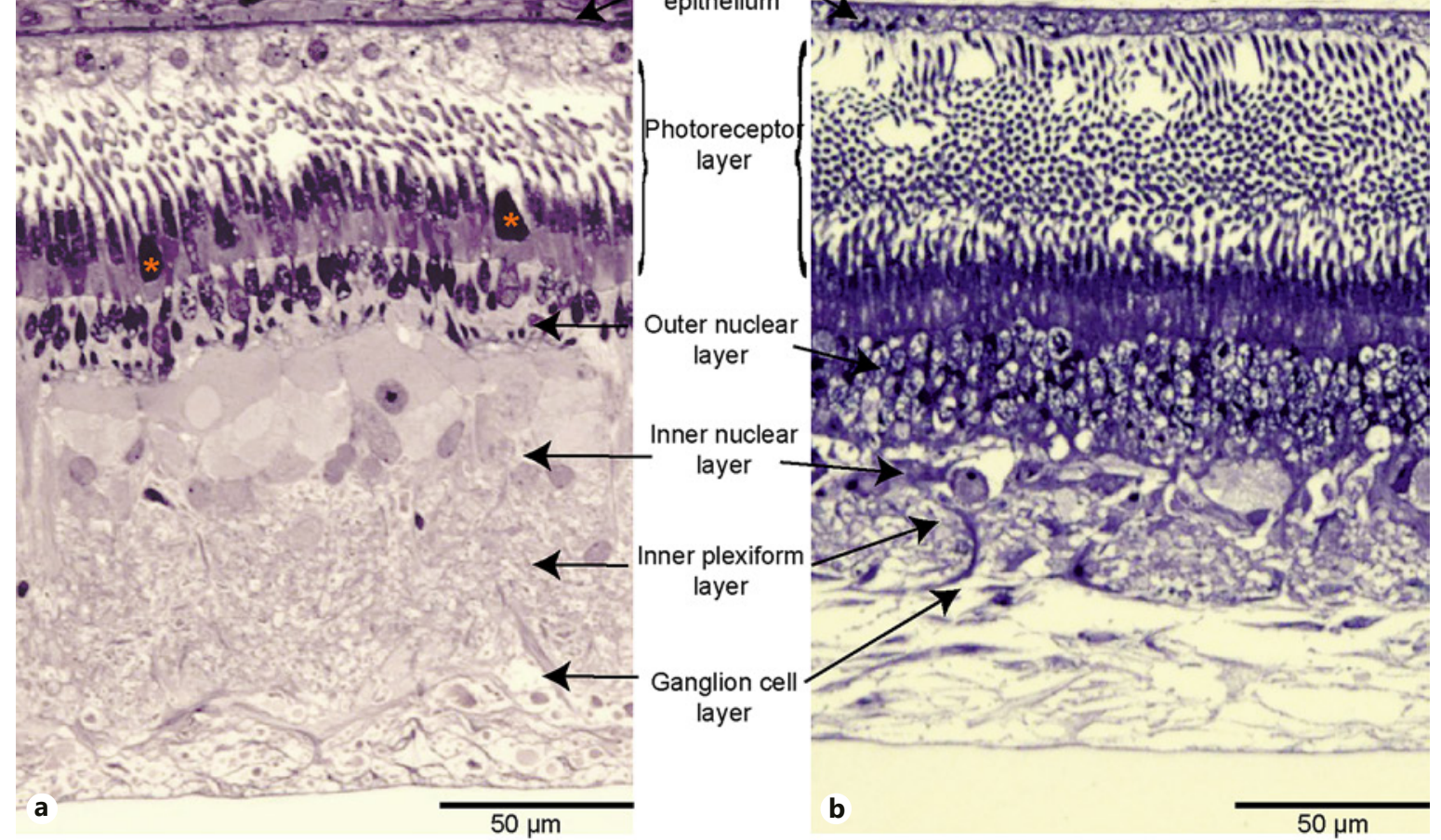

Photorecepto

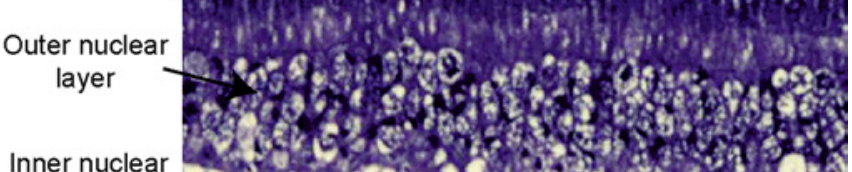

Inner nuclear

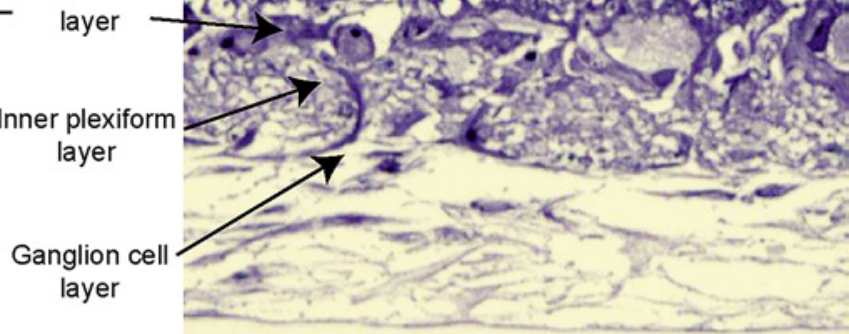

b

$50 \mu \mathrm{m}$

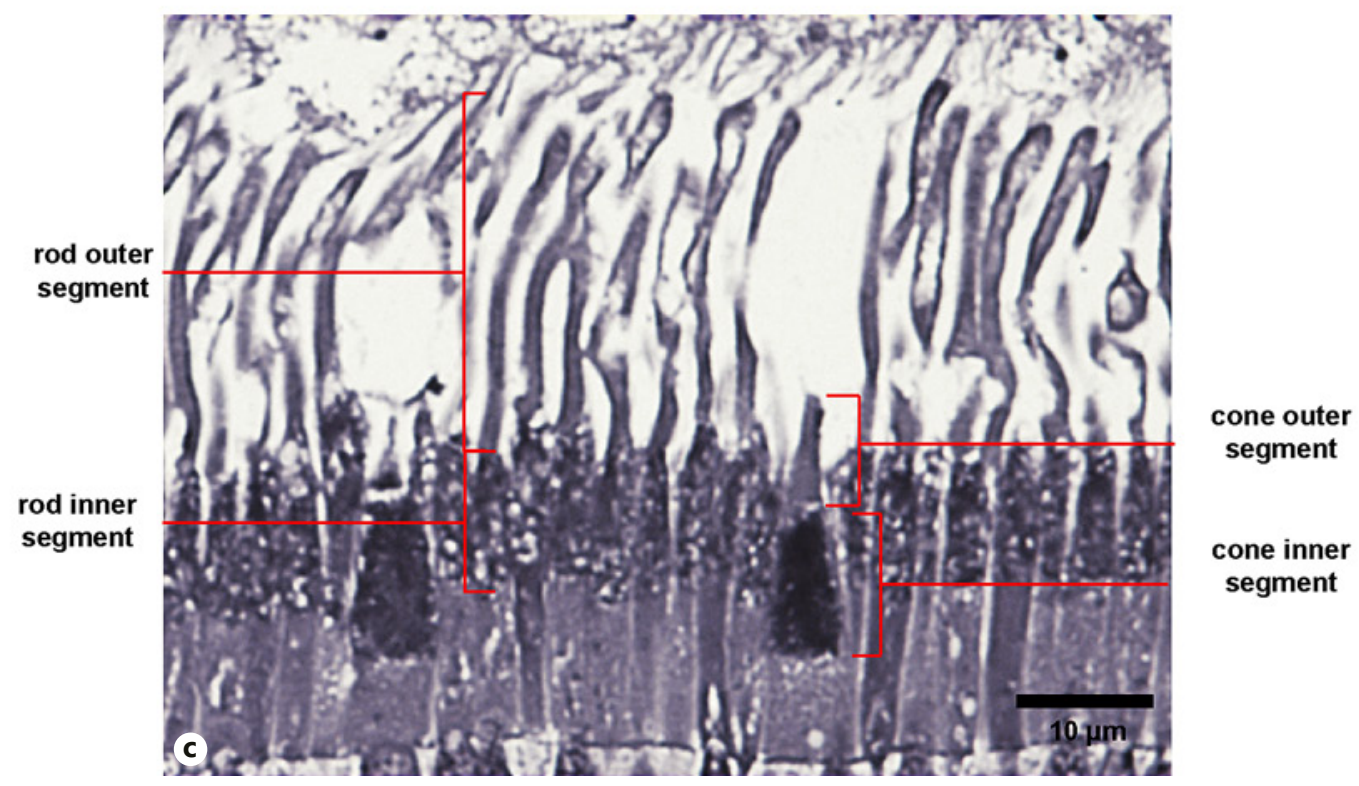

(For legend see next page.)

Brain Behav Evol 2018;92:47-62 DOI: $10.1159 / 000490655$

Garza-Gisholt/Hart/Collin 


\section{Photoreceptor Morphology and Topographic \\ Distribution}

Cones were only observed in the retina of the elephant shark, C. milii. They were characterized by the conical shape of their outer segments, the darkly stained inner segment in transverse section compared to the rods (Fig. 2b), and their average larger inner-segment diameter (6.4 vs. 3.0 $\mu \mathrm{m}$ in rods) when viewed in wholemount (Fig. 3b; Table 1).

Cone distribution in the retina of the elephant shark, C. milii, shows a pronounced horizontal streak across the dorsal meridian of the retina, with three embedded areas of higher density, in the nasal retina, temporal retina, and a shallower area in the central retina. The peak density of cones in the nasal area is 5,896 cells $/ \mathrm{mm}^{2}$, while the peak density of cones in the temporal area is slightly lower at approximately 5,000 cells $/ \mathrm{mm}^{2}$ (Fig. 4).

Rods were observed in all three species of chimaeras, and were characterized by their long, cylindrical outer segments (as seen in transverse section, Fig. 2) and the tight packing of their slender inner segments when viewed in wholemount (Fig. 3). The average length of the rod outer segments varied between the deep-sea chimaeras $(66-68 \mu \mathrm{m})$ and the elephant shark $(34 \mu \mathrm{m})$. The average diameter of the rod outer segments in the elephant shark is slightly smaller $(2.8 \mu \mathrm{m})$ than in the deep-sea chimaeras (R. pacifica $3.4 \mu \mathrm{m}$ and C. lignaria $3.0 \mu \mathrm{m}$ ) (Table 1). The cone density gradient (a centroperipheral gradient of 6:1) is steeper than the rod density gradient (a centroperipheral gradient of 2:1) (Fig. 4). The rod-to-cone ratio within the retinal streak of the elephant shark is around 12:1, rising to $60: 1$ in the periphery.

Rod density varies across the retina in a shallow gradient ranging from 60,000 to 128,000 cells $/ \mathrm{mm}^{2}$ in C. lignaria and from 40,000 to 102,000 cells $/ \mathrm{mm}^{2}$ in R. pacifica, and reveals a weak specialization of increased cell density in the central retina (Fig. 5a, b). C. milii shows a horizontal streak of $>60,000$ cells $/ \mathrm{mm}^{2}$ and two areas, one nasal and the other temporal, both with a peak of $>80,000$ cells/ $\mathrm{mm}^{2}$ (Fig. 5c). The cumulative distribution function shows a steep slope in the mean of the cell densities confirming the shallow gradient. The rod density peaks in the deep-sea chimaeras and reaches around 128,000 cells/ $\mathrm{mm}^{2}$ in the Carpenter's chimaera, C. lignaria and 102,000 cells $/ \mathrm{mm}^{2}$ in the Pacific spookfish, $R$. pacifica. Although the topographic distribution of rods in the retinas of the deep-sea chimaeras did not show a pronounced specialization, the density numbers of rods were higher than in the retina of the elephant shark (Fig. 5d).

Table 1. Total number of photoreceptor cells per retina and in the peak of the specialization

\begin{tabular}{lrrr}
\hline Photoreceptors & C. lignaria & R. pacifica & C. milii \\
\hline Rods $(n=50)$ & & & $48,127,052$ \\
$\quad$ Total number of cells & $288,337,877$ & 83,000 & 3.01 \\
Peak cell density, cells $/ \mathrm{mm}^{2}$ & 128,000 & $113,020,000$ & 13.01 \\
IS diameter, $\mu \mathrm{m}$ & 3.46 & 102,000 & 2.84 \\
IS length, $\mu \mathrm{m}$ & 8.99 & 67.87 & 34.36 \\
OS diameter, $\mu \mathrm{m}$ & 3.032 & 3.43 & \\
OS length, $\mu \mathrm{m}$ & 66.285 & 67.84 & \\
\hline Cones $(n=30)$ & & & $2,095,804$ \\
Total number of cells & & & 5,896 \\
Peak cell density, cells $/ \mathrm{mm}^{2}$ & & & 6.41 \\
IS diameter, $\mu \mathrm{m}$ & & & 11.07 \\
IS length, $\mu \mathrm{m}$ & & & 3.13 \\
OS diameter, $\mu \mathrm{m}$ & & & 6.64 \\
OS length, $\mu \mathrm{m}$ & & & \\
\hline
\end{tabular}

IS, inner segment; OS, outer segment.

Fig. 2. Retinal morphology. a Transverse section of the retina of the elephant shark, C. milii. Note the presence of cones marked with asterisks. b Transverse section of the retina of the Carpenter's chimaera, C. lignaria. Note the presence of only rods and the long outer segments compared to the elephant shark in (a). c Transverse section of the retina in the elephant shark at high magnification to show the cones and the division between the outer and inner segments of the photoreceptors.
Retinal Morphology and Visual Specializations in Chimaeras Species 

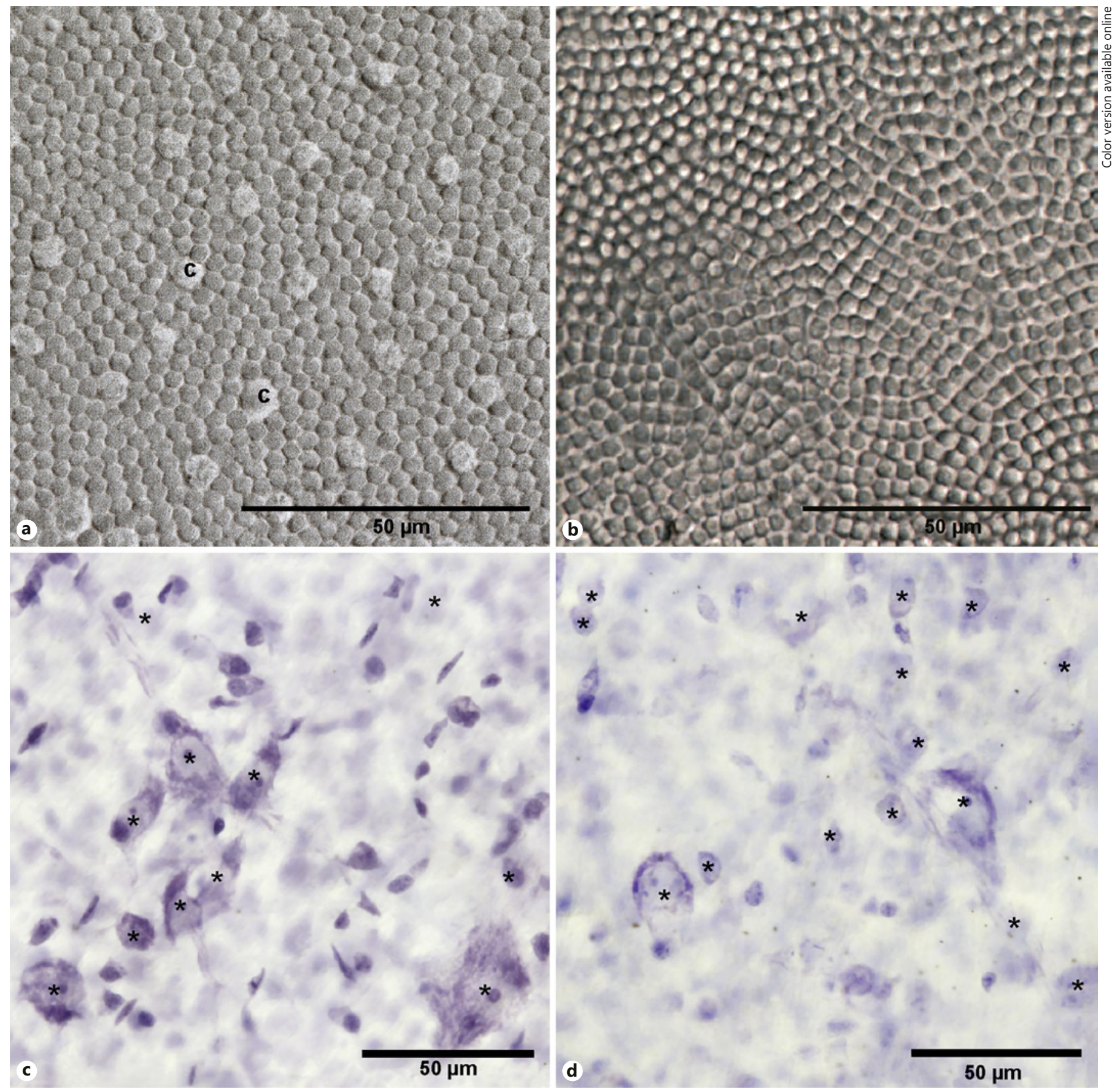

Fig. 3. Axial view of the wholemount retina. a Photoreceptor cell layer in the elephant shark, C. milii. Note the inner segments of the cones (C). b Photoreceptor cell layer of the Carpenter's chimaera, C. lignaria, focused in the inner segments showing a rod-only retina. c Ganglion cell layer in the elephant shark. d Ganglion cell layer in the Carpenter's chimaera. Asterisks denote ganglion cells. 


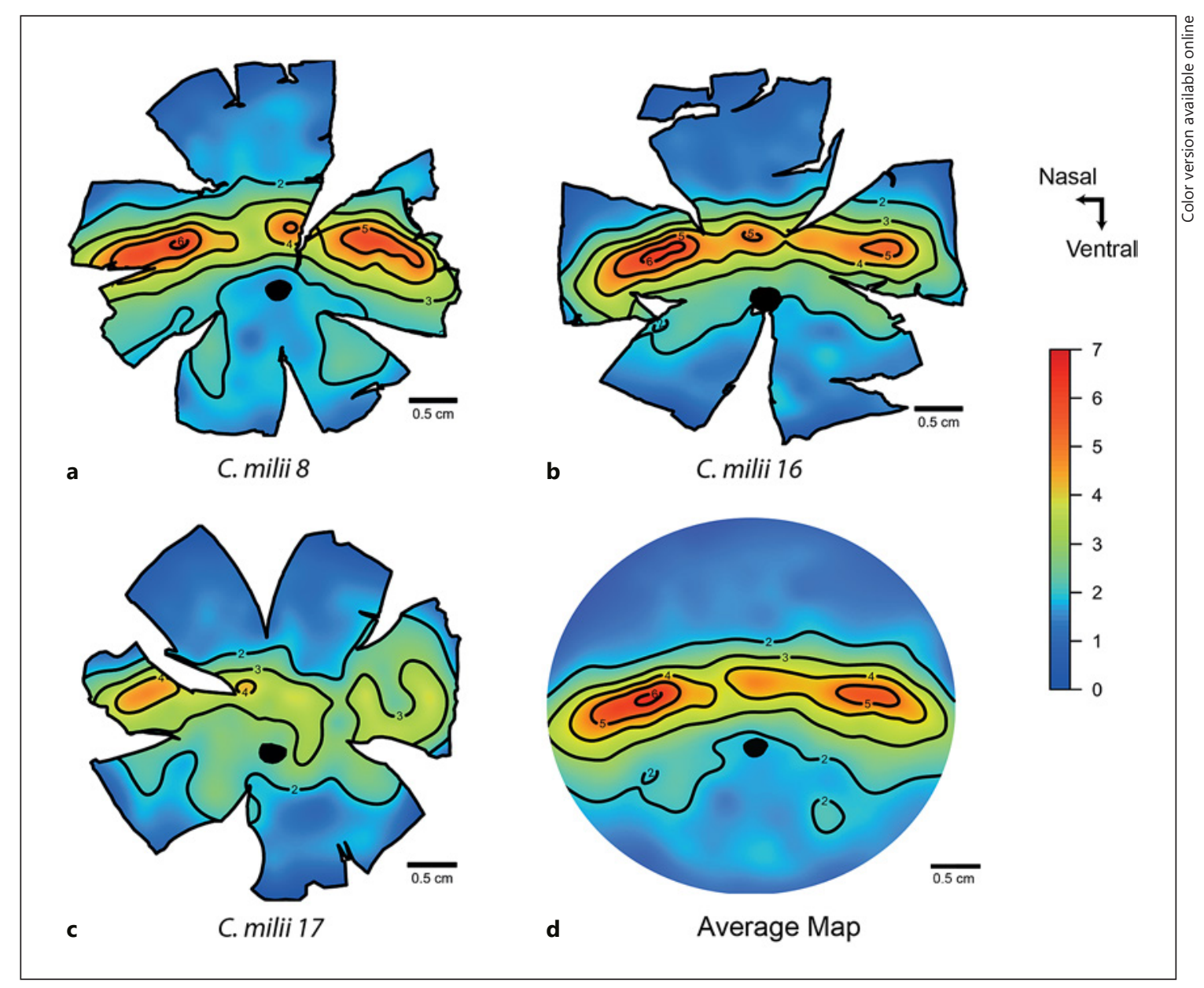

Fig. 4. a-c Topographic maps of the individual cone photoreceptor distributions in 3 different $C$. milii individuals, showing intraspecific variation and the original contour of the retinas including the radial cuts made to flatten the retina. $\mathbf{d}$ Elephant shark average cone topographic map. Color scale represents $\times 1,000$ of cells per $\mathrm{mm}^{2}$.

\section{Ganglion Cell Characterization and Topography}

The ganglion cell distribution shows a horizontal streak in all three species, and within the streak, there are specialized areas or secondary peak(s) in cell density in different parts of the retina. In C. lignaria, there is a nasal area (Fig. 6a) whereas there are two areas in R. pacifica, one nasal and the other temporal (Fig. 6b). These two deep-sea species show a similar peak cell density, i.e., 275 cells $/ \mathrm{mm}^{2}$ in $R$. pacifica and 215 cells $/ \mathrm{mm}^{2}$ in C. lignaria. In contrast, $C$. milii shows a temporal area with a peak cell density of 769 cells $/ \mathrm{mm}^{2}$ and a dorsal specialization of lower magnitude of about 200 cells $/ \mathrm{mm}^{2}$ (Fig. 6c). The mean soma size (area) of the ganglion cells is similar in all three species at $200 \mu \mathrm{m}^{2}$ (Table 2) but varies between 30 and almost $900 \mu \mathrm{m}^{2}$.

Retinal Morphology and Visual Specializations in Chimaeras Species

\section{Summation Maps}

The retina of the elephant shark shows a lower summation ratio, suggesting finer sampling (enhanced resolution) than that of the deep-sea chimaeras, which may rely more on sensitivity (Fig. 7). The horizontal streak is pronounced in all three species: $<1,000$ rods/ganglion cell in C. lignaria, 500 rods/ganglion cell in R. pacifica, and $<200$ rods/ganglion cell in C. milii. Interestingly, in the elephant shark, there is a high summation ratio in the dorsotemporal area with $>500$ rods/ganglion cell, indicative of a higher sensitivity area in the dorsal part of the retina, a region that subtends the substrate within the lower visual field (Fig. 7c). C. lignaria shows higher summation ratios in the dorsal and ventral retina, and has a higher mean summation ratio (1,750 rods/ganglion cell, 


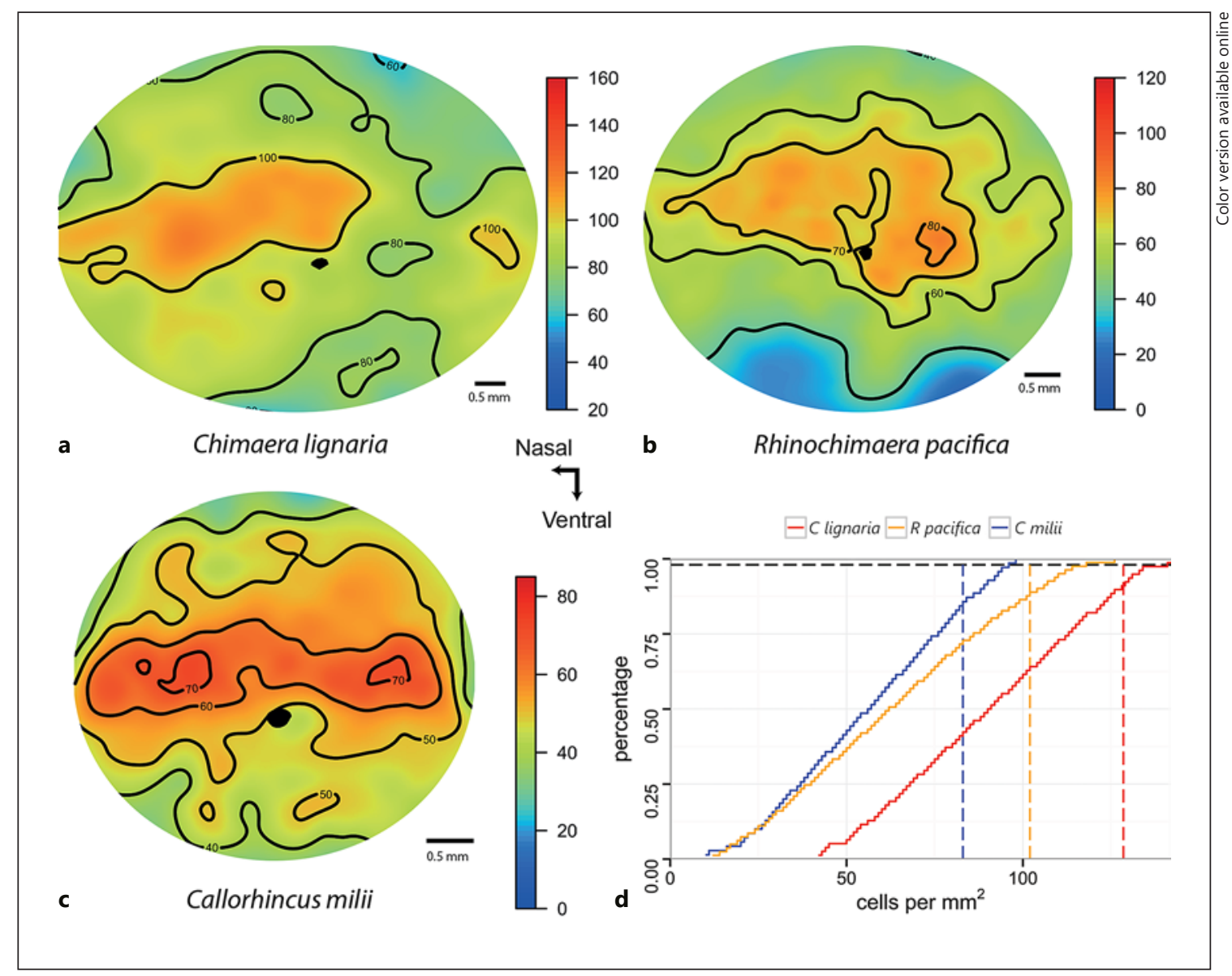

Fig. 5. Isodensity contour maps of rod photoreceptor distribution. a Carpenter's chimaera average map. b Pacific spookfish average map. c. Elephant shark average map. d Empirical cumulative distribution function for the rod population of the 3 maps. Dashed lines represent the peak value at $98 \%$ of the distribution. Color scale represents $\times 1,000$ of cells per $\mathrm{mm}^{2}$.

Table 2. Total number of ganglion cells per retina and in the peak of the specialization

\begin{tabular}{lccc}
\hline Ganglion cells & C. lignaria & R. pacifica & C. milii \\
\hline Total number of cells & 176,498 & 217,144 & 220,166 \\
Peak cell density, cells/mm ${ }^{2}$ & 215 & 275 & 769 \\
Cell area (mean), $\mu \mathrm{m}^{2}$ & 183.84 & 194.96 & 178.46 \\
Cell area (range), $\mu \mathrm{m}^{2}$ & $34-894$ & $55-593$ & $50-626$ \\
\hline
\end{tabular}

calculated over the whole retina) than R. pacifica (700 rods/ganglion cell), while C. milii shows little variation in mean summation ratio (300 rods/ganglion cell) (Fig. $7 \mathrm{~d}$ ).

\section{SRP and Optical Sensitivity}

The spatial arrangement of the ganglion cells in the retina of the chimaeras was not analyzed and so the anatomical SRP was calculated based on the possibility that it was packed in either a square or hexagonal mosaic for comparison. The difference between the two methods was $<10 \%$, with the square method calculated to be lower using the peak in the ganglion cell population. C. lignaria has a higher SRP of almost 3 cycles/degree, while $R$. pacifica has an SRP of 2.6 cycles/degree, and C. milii has an SRP of 2.5 cycles/degree, calculated assuming a hexagonal cell distribution (Table 3). 


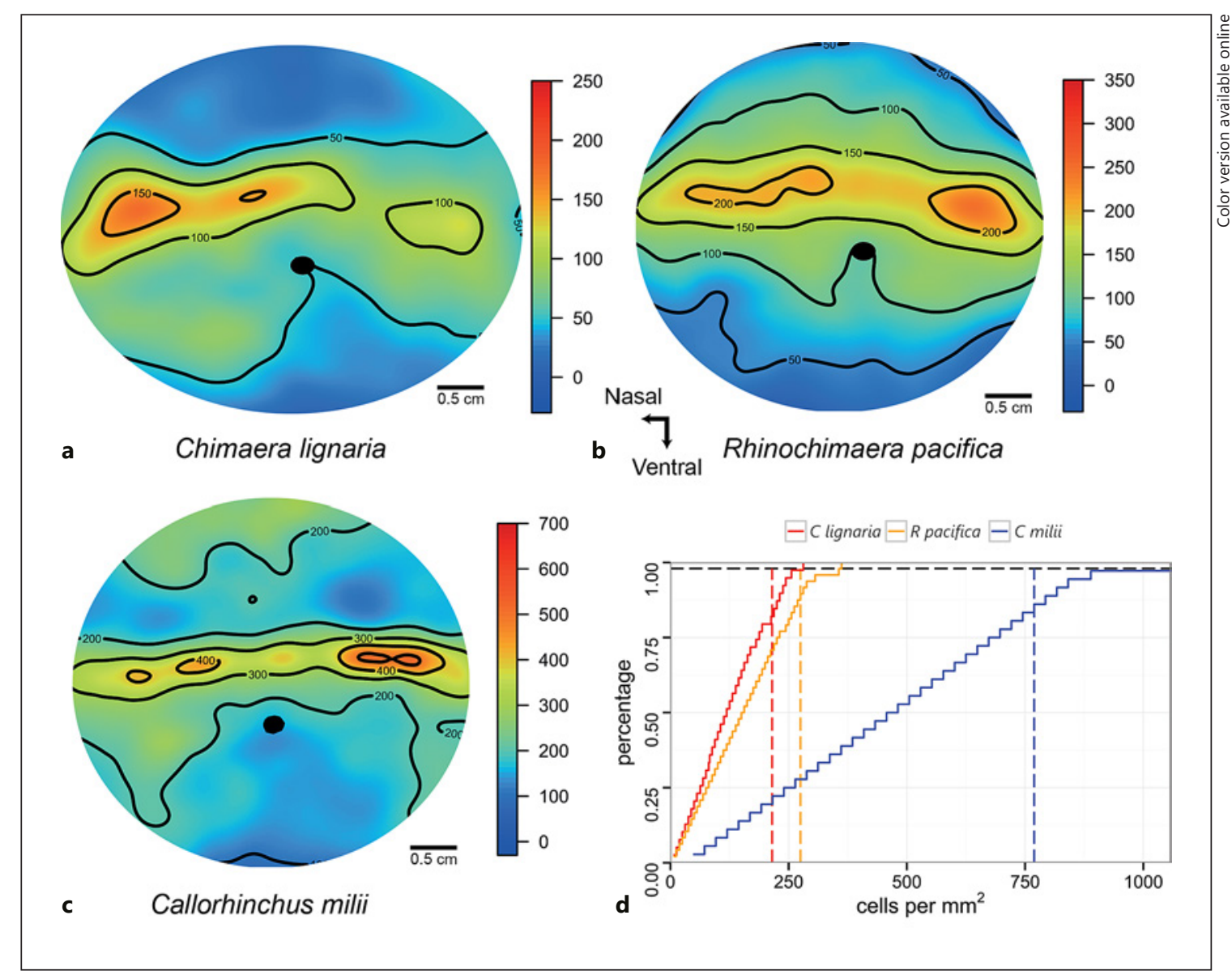

Fig. 6. Isodensity contour maps of the ganglion cell distribution. a Carpenter's chimaera average map. b Pacific spookfish average map. c Elephant shark average map. d Empirical cumulative distribution function for the ganglion cell population of the 3 maps. Dashed lines represent the peak value at $98 \%$ of the distribution.

Table 3. Morphometric measurements and calculations of lens size, spatial resolving power, and optical sensitivity for the 3 chimaera species

\begin{tabular}{lcrc}
\hline & C. lignaria & R. pacifica & C. milii \\
\hline Lens diameter $(A), \mathrm{mm}$ & 21.74 & 14.03 & 9.86 \\
Focal length $(f), \mathrm{mm}$ & 27.72 & 17.89 & 12.57 \\
Spatial resolving power (square), cycles/degree & 2.74 & 2.44 & 2.35 \\
Spatial resolving power (hexagonal), cycles/degree & 2.94 & 2.62 & 2.52 \\
Outer-segment absorbance $(k), \mu \mathrm{m}$ & $0.028^{\mathrm{a}}$ & $0.028^{\mathrm{a}}$ & $0.028^{\mathrm{a}}$ \\
Photon absorption $\left(F_{\lambda_{\max }}\right)$ & 0.84 & 0.85 & 0.62 \\
Optical sensitivity, $\mu \mathrm{m}^{2} \mathrm{sr}$ & 2.94 & 3.81 & 1.89 \\
\hline
\end{tabular}

a Taken from Partridge et al. [1989].

Both the optical sensitivity and light absorption revealed higher values for the deep-sea chimaeras than for C. milii which ventures into shallow water to reproduce. The long rod outer segments increase photon absorption, with $\mathrm{F}_{\lambda \max }$ of 0.84 and 0.85 in the two species of deep-sea chimaeras, $C$. lignaria and $R$. pacifica, respectively. In contrast, C. milii has a lower predicted photon absorption, $\mathrm{F}_{\lambda \max } 0.62$. The optical sensitivity was higher in the 


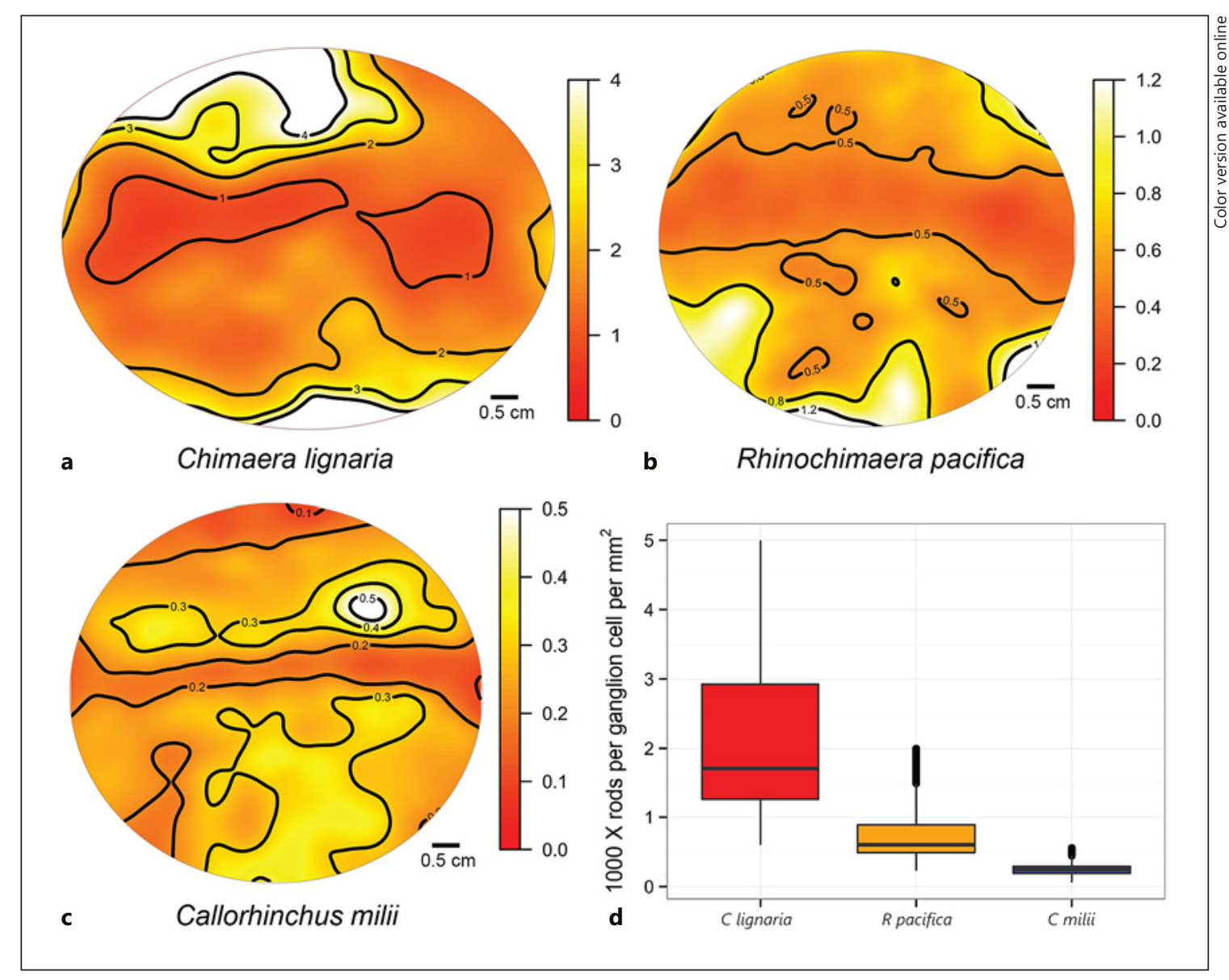

Fig. 7. Summation maps showing the ratio of rod cells/ganglion cell $(\times 1,000)$. a Carpenter's chimaera map. b Pacific spookfish map. c Elephant shark map. d Boxplots represent the frequency distribution of the summation ratios in the retinas of the 3 species.

deep-sea chimaeras, $3.8 \mu \mathrm{m}^{2} \mathrm{sr}$ in $R$. pacifica and $2.9 \mu \mathrm{m}^{2}$ sr in C. lignaria, while the lowest value was found in $C$. milii, i.e., $1.9 \mu \mathrm{m}^{2}$ sr.

\section{Discussion}

The elephant shark, C. milii, displays visual specializations that improve their ability to move between deep water (where the amount of sunlight is reduced) to shallow water (where bright-light conditions prevail) to reproduce during autumn. The presence of cones and potentially color vision, the lower number of rods, the smaller size of the rod outer segments, and the higher number of ganglion cells are all adaptations to optimize vision in the upper part of the water column, where light levels are higher than in the darker mesopelagic zone of the deep sea. In contrast, the two species of deep-sea chimaeras show specializations that reflect the fact that they exclusively inhabit a much dimmer environment, where levels of sunlight are low and bioluminescent light sources predominate. These specializations include the presence of a highly reflective (with a green reflex) tapetum lucidum, higher rod densities, longer and wider rod outer segments, and a higher summation ratio.

The mean length of the rod outer segments in C. lignaria and $R$. pacifica (approx. 66-68 $\mu \mathrm{m}$ ) are consistent with other deep-sea chimaeras such as $H$. mirabilis (64 $\mu \mathrm{m})$ [Fröhlich et al., 1995], Hydrolagus affinis $(46.6 \mu \mathrm{m})$ [Denton and Nicol, 1964], and C. monstrosa (50 $\mu \mathrm{m})$ [Vigh-Teichmann et al., 1990], all of which live at a depth of $<600 \mathrm{~m}$. In contrast, the rod outer segments of the elephant shark, C. milii ( $35 \mu \mathrm{m})$, are similar to H. colliei (22 $\mu \mathrm{m})$ [Maddock and Nicol, 1978], which has been report- 
ed at a depth of $80 \mathrm{~m}$, but that, like C. milii, also ventures into shallow water [Last and Stevens, 2009]. Compared to some elasmobranchs, the rod outer-segment length in chimaerids is similar to that in nocturnal, benthic elasmobranchs such as the Port Jackson shark (Heterodontus potusjacksoni), the eastern shovelnose ray (Aptychotrema rostrata), and the pink whipray (Himantura fai), all with outer-segment lengths of about $35 \mu \mathrm{m}$ [Litherland and Collin, 2008; Schieber et al., 2012].

Few studies have mapped the topographic distribution of photoreceptors in elasmobranchs. The ornate wobbegong, Orectolobus ornatus, possesses a dorsal elongation with two peaks, one nasal and one temporal (each of about 50,000 rods $/ \mathrm{mm}^{2}$ ). The epaulette shark, Hemiscyllium ocellatum, also has a horizontal streak with a temporal peak of about 80,000 rods $/ \mathrm{mm}^{2}$ [Litherland and Collin, 2008]. The horizontal streak is consistent with the topographic distribution in the elephant shark, C. milii (a peak of 83,000 cells $/ \mathrm{mm}^{2}$ ). The number of rods is higher in the retina of purely deep-sea chimaeras, presumably as an adaptation to increase absolute sensitivity, and, therefore, the detection of objects under low-light conditions. The deep-sea chimaeras $R$. pacifica and C. lignaria have rod peaks of between 102,000 and 128,000 cells $/ \mathrm{mm}^{2}$, consistent with reports of rod density in C. monstrosa of around 100,000 cells $/ \mathrm{mm}^{2}$ [Franz, 1905].

With the presence of three types of cone pigments (Rh2, LWS1, and LWS2) in the elephant shark retina, C. milii is similar to some species of rays that live in shallow water [Hart et al., 2004; Davies et al., 2009]. The complement of cone receptor types extends sensitivity across more of the visible spectrum and provides the potential for color vision. The ability to discriminate color appears to have been lost in true sharks (Selachii), which possess only a single cone type in addition to a rod [Hart et al., 2011; Theiss et al., 2012]. The low rod-to-cone ratio (12: 1 ) in the elephant shark is similar to species of sharks and rays that live in dim-light conditions, i.e., $H$. ocellatum (18:1), O. ornatus (19:1) [Litherland and Collin, 2008], and Isurus oxyrinchus (10:1) [Gruber et al., 1975]. This predicts that elephant sharks have high-sensitivity vision in darker environments but still have spatial resolution of objects when they migrate into shallow, brightly lit estuaries to reproduce.

The calculated optical sensitivities of the deep-sea chimaeras are relatively high when compared to the elephant shark because their rod outer segments are almost twice the length of those of C. milii. Optical sensitivity is a relative measure because other factors affect the total sensitivity of the eye [Land, 1981]. The use of monochromatic light for the calculation is adequate for the deep-sea species and for species that detect bioluminescence [Warrant and Locket, 2004]. The values of optical sensitivity calculated for the chimaeras (range 1.9-3.8 $\mu^{2} \mathrm{sr}$ ) are consistent with the values obtained for bony fishes such as the blue marlin and the blue tuskfish, i.e., 2.8 and $1.4 \mu \mathrm{m}^{2} \mathrm{sr}$, respectively, based on their double cones that are the largest type of photoreceptor in their retina [Fritsches et al., 2003].

All the topographic maps of ganglion cell density for the three species of chimaerids show a similar pattern to the large-eyed rabbitfish $H$. mirabilis [Bozzano and Collin, 2000] and spotted ratfish H. colliei [Collin, 1999], which possess a dorsal horizontal streak with both a nasal and temporal area for acute vision. In $H$. colliei, the density of cells in the temporal area $\left(1,500\right.$ cells $\left./ \mathrm{mm}^{2}\right)$ is higher than in the nasal area $\left(1,300 \mathrm{cells} / \mathrm{mm}^{2}\right)$ [Bozzano and Collin, 2000] as is to be found in the elephant shark $C$. milii and the Pacific spookfish R. pacifica. The presence of a dorsally located horizontal streak probably reflects the fact that they live in open areas near the substrate, where they need to sample objects at the sand-water interface across a large panoramic field [Hughes, 1975, 1977; Collin and Pettigrew, 1988b]. The peak ganglion cell density within this specialization varies within the Holocephali. H. mirabilis and C. monstrosa possess peaks of 1,600 [Bozzano and Collin, 2000] and 600 [Franz, 1905] ganglion cells $/ \mathrm{mm}^{2}$, respectively, compared to 215 , 275 , and 769 ganglion cells $/ \mathrm{mm}^{2}$ in C. lignaria, R. pacifica, and $C$. milii, respectively.

The mean area of the ganglion cell soma is larger in chimaerids (with some reaching nearly $900 \mu \mathrm{m}^{2}$ ) than any other species of Chondrichthyes examined, i.e., about three times larger than in the deep-sea shark Etmopterus spinax [Bozzano and Collin, 2000] and six times larger than a range of other elasmobranchs $\left(150 \mu \mathrm{m}^{2}\right)$ [Bozzano and Collin, 2000]. We observed a greater proportion of large ganglion cells than small ganglion cells, which could have been displaced to the inner nuclear or inner plexiform layers [Stell and Witkovsky, 1973; Collin, 1988; Muguruma et al. 2014] and therefore not counted. The large ganglion cells may therefore represent a subpopulation of ganglion cells that also have large dendritic fields and be involved in the detection of movement [Barlow, 1953; Boycott and Wässle, 1974]. Another alternative is that giant ganglion cells provide a large visual angle like in the smooth dogfish, Mustelus canis, where these cells, each occupying an area of $>700 \mu \mathrm{m}^{2}$, subtend a visual angle of $6^{\circ}$ [Stell and Witkovsky, 1973]. 
The anatomical SRP calculated using ganglion cell density is arguably a better indicator than values calculated using photoreceptor density, since the ganglion cells are the output neurons of the retina. The ratio of photoreceptors to ganglion cells (or the convergence of information) represents a trade-off between spatial resolution and sensitivity [Pettigrew et al., 1988; Fritsches et al., 2003]. The low SRP calculated for these three species of chimaeras (approx. 2.6 cycles per degree) is similar and within range of that calculated for a number of elasmobranchs, i.e., 2-11 cycles per degree [Lisney and Collin, 2008]. It is possible that the SRP was underestimated because some of the smaller ganglion cells may have been omitted from the counts (as they would have resembled amacrine cells) and/or because the inner nuclear and inner plexiform layers were not sampled. However, the error for the morphological estimate is unlikely to be larger than the error obtained when visual acuity is examined using behavioral methods [Collin and Pettigrew, 1989].

The presence of a dorsal horizontal streak in the elephant shark, with a low number of rods per ganglion cell (summation ratio), is a specialization that potentially allows this species to distinguish small objects on the substrate. The summation ratio in the deep-sea chimaeras is appreciably higher than in the elephant shark. A high summation ratio potentially increases sensitivity in the low-light conditions of the deep sea, albeit at the expense of acuity. Some teleost fishes possess other specializations to increase sensitivity like the grouping of photoreceptors to increase the ability to capture photons, but the chimaeras only have high densities of photoreceptors with no grouping observed [Wagner et al., 1998; Warrant and Locket, 2004; Douglas, 2010]. The high density of photoreceptors and their convergence on a relatively small number of large ganglion cells represents a specialization to increase sensitivity in environments with dim light, a useful adaptation to allow these species to be alerted to the presence of potential prey or predators as soon as an object enters their visual field [Bozzano and Collin, 2000].

The perception of environmental cues such as finding food, detecting possible predators, and finding potential mates to reproduce is a complex interaction of many different senses. This study suggest that vision plays an important role in each species' ability to navigate within their environment. Further studies require more attention to other senses and how they transmit sensory information to the central nervous system. Brain studies on Rhinochimaerids have revealed that the anterior lateralline lobe is well developed, where vision, lateral line, and elecroreception are important sources of sensory input for this group of early vertebrates [Yopak and Montgomery, 2008]. All these senses operate over relatively close ranges, which might be useful for both finding food and social communication. Chimaeras use mechanisms like spines on their claspers and head (in males) to attach to the females, but first they need to get close enough to their reproductive partners [LaMarca, 1964] and so vision is important in the recognition of potential mates. Feeding strategies vary in the Rhinochimaeridae and Chimaeridae, which feed on benthic or pelagic invertebrates, respectively, and may even indicate the relative importance of different senses. Rhinochimaerid species have a prominent snout and a relatively high number of electroreceptors with well-developed lateral-line canals that can detect buried, benthic prey. On the other hand, chimaerid species likely rely more on vision to detect pelagic (and possibly bioluminescent) prey [Gonzalez et al., 2007]. The use of additional species of each family would reveal more information about the phylogenetic relationships of the retinal specializations within the group. The callorhinchid family is basal compared to the rhinochimaerid and chimaerid families [Inoue et al., 2010; Didier et al., 2012]. The presence of a more sensitive retina in chimaerids and rhinochimaerids might be a byproduct of the evolutionary divergence of this group after these species moved into deeper waters, while the presence of color vision in the more basal callorhincids may be related to their use of shallower, brighter-lit habitats for reproduction.

\section{Acknowledgements}

We would like to express our gratitude to Milan Barbarich, Managing Director of Anton's Seafoods Ltd., Auckland, NZ, for allowing us access to "Sea Mount", and to all the crew of the ship for facilitating the sampling of the species. We would like to thank Amy Newman for her efforts to collect Carpenter's chimaera and Pacific spookfish. We also appreciate help from Camila Martins, Richard Reyna, and Matt Cini in collecting samples of elephant sharks in Queenscliff, VIC, Australia. We are sincerely thankful to Joao Paulo Coimbra and Caroline Kerr for all the invaluable help in the lab. E.G.-G. was supported by a Mexican scholarship for postgraduate studies (CONACyT) and the Ad-Hoc Top-Up Scholarship from the University of Western Australia. The research was supported by an ARC discovery grant (DP110103294) and the Sea World Research and Rescue Foundation SWR/3/2012.

\section{Disclosure Statement}

The authors declare that no competing interests exist.
Garza-Gisholt/Hart/Collin 


\section{Author Contributions}

All authors had full access to all the data in the study and take responsibility for the integrity of the data, the accuracy of data analysis, and the study concept and design. Acquisition of data: E.G.-G. Analysis and interpretation of data: E.G.-G., N.S.H., and
S.P.C. Drafting of the manuscript: E.G.-G. Critical revision of the manuscript for important intellectual content: E.G.-G., N.S.H., and S.P.C. Statistical analysis: E.G.-G. and N.S.H. Obtained funding: E.G.-G., N.S.H., and S.P.C. Administrative, technical, and material support, and study supervision: N.S.H. and S.P.C.

\section{References}

Baddeley A, Turner R (2005): spatstat: An R package for analyzing spatial point patterns. J Stat Softw 12:1-42.

Barlow HB (1953): Summation and inhibition in the frog's retina. J Physiol 119:69-88.

Beatty DD (1969): Visual pigments of three species of cartilaginous fishes. Nature 222:285.

Bergstad OA, Wik AD, Hildre O (2003): Predator-prey relationships and food sources of the Skagerrak deep-water fish assemblage. J Northw Atl Fish Sci 31:165-180.

Boycott BB, Wässle H (1974): The morphological types of ganglion cells of the domestic cat's retina. J Physiol 240:397-419.

Bozzano A (2004): Retinal specialisations in the dogfish Centroscymnus coelolepis from the Mediterranean deep-sea. Sci Mar 68:185-195.

Bozzano A, Collin SP (2000): Retinal ganglion cell topography in elasmobranchs. Brain Behav Evol 55:191-208.

Bozzano A, Murgia R, Vallerga S, Hirano J, Archer SN (2001): The photoreceptor system in the retinae of two dogfishes, Scyliorhinus canicula and Galeus melastomus: possible relationship with depth distribution and predatory lifestyle. J Fish Biol 59:1258-1278.

Carter GSS (1948): Colour and colour vision in animals. Nature 4120:439-440.

Coimbra JP, Marceliano ML V, Andrade-da-Costa BLD, Yamada ES (2006): The retina of tyrant flycatchers: topographic organization of neuronal density and size in the ganglion cell layer of the great kiskadee Pitangus sulphuratus and the rusty margined flycatcher Myiozetetes cayanensis (Aves: Tyrannidae). Brain Behav Evol 68:15-25.

Coimbra JP, Trevia N, Marceliano ML V, Andrade-Da-Costa BLD, Picanco-Diniz CW, Yamada ES (2009): Number and distribution of neurons in the retinal ganglion cell layer in relation to foraging behaviors of tyrant flycatchers. J Comp Neurol 514:66-73.

Collin SP (1999): Behavioural ecology and retinal cell topography; in Archer SN, Djamgoz MBA, Loew ER, Partridge JC, Vallerga S (eds): Adaptive Mechanisms in the Ecology of Vision, pp 509-535.

Collin SP (1988): The retina of the shovel-nosed ray, Rhinobatos batillum (Rhinobatidae): morphology and quantitative analysis of the ganglion, amacrine and bipolar cell populations. Exp Biol 47:195.
Collin SP, Pettigrew JD (1988a): Retinal ganglioncell topography in teleosts - a comparison between Nissl-stained material and retrograde labeling from the optic-nerve. J Comp Neurol 276:412-422.

Collin SP, Pettigrew JD (1989): Quantitative comparison of the limits on visual spatial resolution set by the ganglion cell layer in 12 species of reef teleosts. Brain Behav Evol 34:184-192.

Collin SP, Pettigrew JD (1988b): Retinal topography in reef teleosts II. Some species with prominent horizontal streaks and high-density areae. Brain Behav Evol 31:283-295.

Collin SP (2008): A Web-based archive for topographic maps of retinal cell distribution in vertebrates: invited paper. Clin Exp Optom 91:85-95.

Compagno LJ V (2001): Sharks of the World: An Annotated and Illustrated Catalogue of Shark Species Known to Date. 2. Carcharhiniformes. Rome, FAO Food and Agriculture Organization of the United Nations.

Compagno LJ V, Dando M, Fowler S (2005): Sharks of the World. Princeton, Princeton University Press.

Crescitelli F (1969): The visual pigment of a chimaeroid fish. Vision Res 9:1407-1414.

Davies WL, Carvalho LS, Tay BH, Brenner S, Hunt DM, Venkatesh B (2009): Into the blue: gene duplication and loss underlie color vision adaptations in a deep-sea chimaera, the elephant shark Callorhinchus milii. Genome Res 19:415-426.

De Busserolles F, Marshall NJ (2017): Seeing in the deep-sea: visual adaptations in lanternfishes. Phil Trans R Soc B 372:20160070.

Denton EJ, Nicol JAC (1964): The chodioidal tapeta of some cartilaginous fishes (Chondrichthyes). J Mar Biol Assoc UK 44:219-258.

Denton EJ, Shaw T (1963): The visual pigments of some deep-sea elasmobranchs. J Mar Biol Assoc UK 43:65-70.

Didier DA (2004): Phylogeny and classification of extant Holocephali; in Carrier JC, Musick JA, Heithaus MR (eds): Biology of Sharks and Their Relatives. Boca Raton, CRC Press, pp 115-136.

Didier DA (1998): The leopard Chimaera, a new species of chimaeroid fish from New Zealand (Holocephali, Chimaeriformes, Chimaeridae). Ichthyol Res 5:281-289.
Didier DA, Kemper JM, Ebert DA (2012): Phylogeny, biology and classification of extant holocephalans; in Carrier JC, Musick JA, Heithaus MR (eds): Biology of Sharks and Their Relatives, ed 2. Boca Raton, CRC Press, pp 97-123.

Douglas RH (2010): Vision: vertebrates; in Breed MD, Moore J (eds): Encyclopedia of Animal Behavior. Oxford, Academic Press, pp 525542

Douglas RH, Partridge JC, Hope AJ (1995): Visual and lenticular pigments in the eyes of demersal deep-sea fishes. J Comp Physiol A 177: $111-122$

Dunn MR, Griggs L, Forman J, Horn P (2010): Feeding habits and niche separation among the deep-sea chimaeroid fishes Harriotta raleighana, Hydrolagus bemisi and Hydrolagus novaezealandiae. Mar Ecol Ser 407:209-225.

Ebert DA (ed) (2003): Sharks, Rays, and Chimaeras of California. Los Angeles, University of California Press.

Franz V (1905): Zur Anatomie, Histologie und funktionellen Gestaltung des Selachierauges. Jena Z Naturw 40:697-840.

Fritsches KA, Marshall NJ, Warrant EJ (2003): Retinal specializations in the blue marlin: eyes designed for sensitivity to low light levels. Mar Freshw Res 54:333-341.

Fröhlich E, Negishi K, Wagner H-J (1995): Patterns of rod proliferation in deep-sea fish retinae. Vision Res 35:1799-1811.

Garcia VB, Lucifora LO, Myers RA (2008): The importance of habitat and life history to extinction risk in sharks, skates, rays and chimaeras. Proc R Soc B Biol Sci 275:83-89.

Garza-Gisholt E, Hemmi JM, Hart NS, Collin SP (2014): A comparison of spatial analysis methods for the construction of topographic maps of retinal cell density. PLoS One 9: e93485.

Gonzalez C, Teruel J, López E, Paz X (2007): Feeding habits and biological features of deep-sea species of the northwest Atlantic: large-eyed rabbitfish (Hydrolagus mirabilis), narrownose chimaera (Harriotta raleighana) and black dogfish (Centroscyllium fabricii). Northwest Atlantic Fisheries Organization Scientific Council Meeting, Dartmouth, NS, Canada, doc. 07/63 (9 pages).

Gruber SH, Gulley RL, Brandon J (1975): Duplex retina in seven elasmobranch species. Bull Mar Sci 25:353-358.
Retinal Morphology and Visual Specializations in Chimaeras Species
Brain Behav Evol 2018;92:47-62 
Hart NS (2002): Vision in the peafowl (Aves: Pavo cristatus). J Exp Biol 205:3295-3935.

Hart NS, Lisney T, Collin SP (2006): Visual communication in elasmobranchs; in Ladich F, Collin SP, Moller P, Kapoor BG (eds): Communication in Fishes. Enfield, Science Publishers, pp 337-392.

Hart NS, Lisney T, Marshall NJ, Collin SP (2004): Multiple cone visual pigments and the potential for trichromatic colour vision in two species of elasmobranch. J Exp Biol 207:45874594.

Hart NS, Theiss SM, Harahush BK, Collin SP (2011): Microspectrophotometric evidence for cone monochromacy in sharks. Naturwissenschaften 98:193-201.

Herring PJ (1977): Bioluminescence of marine organisms. Nature 267:788-793.

Herring PJ (2000): Bioluminescent signals and the role of reflectors. J Pure Appl Opt 2:R29R38.

Hueter RE (1991): Vision in elasmobranchs - introduction. J Exp Zool 256:1-2.

Hughes A (1975): A comparison of retinal ganglion cell topography in the plains and tree kangaroo. J Physiol 244:61P.

Hughes A (1977): The topography of vision in mammals of contrasting life style: comparative optics and retinal organization; in Crescitelli F (ed): The Visual System in Vertebrates. Berlin, Springer, pp 613-756.

Inoue JG, Miya M, Lam K, Tay BH, Danks JA, Bell J, et al (2010): Evolutionary origin and phylogeny of the modern holocephalans (Chondrichthyes: Chimaeriformes): a mitogenomic perspective. Mol Biol Evol 27:2576-2586.

Kuchnow KP (1971): The elasmobranch pupillary response. Vision Res 11:1395-1406.

LaMarca MJ (1964): The functional anatomy of the clasper and clasper gland of the yellow stingray, Urolophus jamaicensis (Cuvier). J Morphol 114:303-323.

Land MF (1981): Optics and vision in invertebrates; in Autrum H (ed): Handbook of Sensory Physiology. Berlin, Springer, pp 471592.

Last PR, Stevens JD (eds) (2009): Sharks and Rays of Australia, ed 2. Collingwood, CSIRO Publishing.

Lisney T (2010): A review of the sensory biology of chimaeroid fishes (Chondrichthyes; Holocephali). Rev Fish Biol Fish 20:571-590.
Lisney T, Collin SP (2007): Relative eye size in elasmobranchs. Brain Behav Evol 69:266279.

Lisney T, Collin SP (2008): Retinal ganglion cell distribution and spatial resolving power in elasmobranchs. Brain Behav Evol 72:59-77.

Litherland L, Collin SP (2008): Comparative visual function in elasmobranchs: spatial arrangement and ecological correlates of photoreceptor and ganglion cell distributions. Vis Neurosci 25:549-561.

Lund R, Grogan ED (1997): Relationships of the Chimaeriformes and the basal radiation of the Chondrichthyes. Rev Fish Biol Fish 7:65-123.

Maddock RG, Nicol JAC (1978): Studies on the eyes of Hydrolagus (Pisces: Chimaeridae). Contrib Mar Sci 21:77-87.

Marques A, Porteiro F (2000): Hydrothermal vent mussel Bathymodiolus sp. (Mollusca: Mytilidae): diet item of Hydrolagus affinis (Pisces: Chimaeridae). Copeia 3:806-807.

Matthiessen L (1880): Untersuchungen über den Aplanatismus und die Periscopie der Krystalllinsen in den Augen der Fische. Pflügers Arch Eur J Physiol 21:287-307.

Moura T, Figueiredo I, Bordalo-Machado P, Almeida C, Gordo LS (2005): A new deep-water chimaerid species, Hydrolagus lusitanicus $\mathrm{n}$. sp., from off mainland Portugal with a proposal of a new identification key for the genus Hydrolagus (Holocephali: Chimaeridae) in the north-east Atlantic. J Fish Biol 67:742751.

Muguruma K, Takei S, Yamamoto N (2013): Retinal ganglion cell distribution and spatial resolving power in the Japanese catshark Scyliorhinus torazame. Zool Sci 30:42-52.

Muguruma K, Stell, WK, Yamamoto N (2014): A morphological classification of retinal ganglion cells in the Japanese Catshark Scyliorhinus torazame. Brain Behav Evol 83:199-215.

Nicol JAC, Somiya H (1989): The Eyes of Fishes. NY, Oxford University Press.

Nychka D, Furrer R, Sain S (2012): R: fields: Tools for spatial data (Internet). R Package Version 6. http://cran.r-project.org/package=fields.

Partridge JC, Shand J, Archer SN, Lythgoe JN, Groningen-Luyben WAHM (1989): Interspecific variation in the visual pigments of deepsea fishes. J Comp Physiol A 164:513-529.
Pettigrew JD, Dreher B, Hopkins CS, McCall MJ, Brown M (1988): Peak density and distribution of ganglion cells in the retinae of microchiropteran bats: implications for visual acuity. Brain Behav Evol 32:39-56.

R Core Team (2012): R: a language and environment for statistical computing (Internet). http://www.r-project.org/.

R Studio (2012) (Internet). http://www.rstudio. org/.

Schieber NL, Collin SP, Hart NS (2012): Comparative retinal anatomy in four species of elasmobranch. J Morphol 273:423-440.

Schneider CA, Rasband WS, Eliceiri KW (2012): NIH Image to Image J: 25 years of image analysis. Nat Methods 9:671-675.

Stell WK, Witkovsky P (1973): Retinal structure in the smooth dogfish, Mustelus canis: general description and light microscopy of giant ganglion cells. J Comp Neurol 148:1-31.

Stone J (ed) (1981): The Whole Mount Handbook: A Guide to the Preparation and Analysis of Retinal Whole Mounts. London, Maitland Publications.

Theiss SM, Lisney T, Collin SP, Hart NS (2007): Colour vision and visual ecology of the bluespotted maskray, Dasyatis kuhlii Müller \& Henle, 1814. J Comp Physiol A 193:67-79.

Theiss SM, Davies WIL, Collin SP, Hunt DM, Hart NS (2012): Cone monochromacy and visual pigment spectral tuning in wobbegong sharks. Biol Lett 8:1019-1022.

Vigh-Teichmann I, Szel A, Rohlich P, Vigh B (1990): A comparison of the ultrastructure and opsin immnocytochemistry of the pineal organ and retina of the deep-sea fish Chimaera monstrosa. Exp Biol 48:361-371.

Wagner HJ, Frohlich E, Negishi K, Collin SP (1998): The eyes of deep-sea fish II. Functional morphology of the retina. Prog Retin Eye Res 17:637-685.

Warrant EJ, Locket AN (2004): Vision in the deep sea. Biol Rev 79:671-712.

Wickham H (2009): ggplot2: Elegant graphics for data analysis (Internet). New York, Springer. http://had.co.nz/ggplot2/book.

Wickham H (2012): stringr: Make it easier to work with strings (Internet). R Package. http://cran.r-project.org/package=stringr.

Yopak KE, Montgomery JC (2008): Brain organization and specialization in deep-sea chondrichthyans. Brain Behav Evol 71:287-307. 